\title{
Pengaruh Sanksi dari Tindakan Indisipliner terhadap Kinerja Karyawan pada Divisi Collection PT. Summit Oto Finance Pekanbaru
}

\author{
Andry \\ STIE Mahaputra Riau \\ e-mail: Andryse22@yahoo.com
}

\begin{abstract}
The study was conducted at the collection division of PT. Summit Oto Finance Pekanbaru with the aim of research to determine the effect of sanctions from disciplinary actions on employee performance. The number of samples used was 42 people, using the census method. The analysis used is validity test, reliability test, classic assumption test, $F$ test and $T$ test. The results of the analysis using SPSS can be seen that the position reduction variable has a negative effect on performance, transfer of position and termination has a positive effect on employee performance while complaints to parties authority does not affect employee performance. The results of the analysis using the coefficient of determination, the results are $82.2 \%$ and the remaining $17.8 \%$ are not examined
\end{abstract}

Keywords: Indiscipline, Performance

\section{PENDAHULUAN}

Pada umumnya setiap karyawan yang bekerja cenderung memiliki kedisiplinan dan patuh pada setiap aturan dan ketentuan yang ditetapkan oleh organisasi. Para pelanggar kedisiplinan aturan juga biasanya hanya sebagian kecil dari karyawan yang berada di oragnisasi tersebut, yang mana karyawan seperti ini dianggap sebagai karyawan yang bermasalah.

Jika perusahaan gagal menghadapi karyawan yang bermasalah, efek negatif kepada para karyawan lainnya dan kelompok kerja lainya akan timbul. Masalah disiplin yang umumnya yang ditimbulkan para karyawan bermasalah antara lain absensi, bolos, defesiensi produktivitas, alkoholisme, dan ketidakpatuhan.

Ketika karyawan terus bermasalah dalam bidang kedisiplinan maka diperlukan adanya tindakan penegakan disiplin model pendekatan disiplin progresif. Pendekatan disiplin model progresif bertujuan untuk membentuk pribadi karyawan yang benarbenar memiliki mentalistas yang perlu penanganan serius dan dengan pendekatan yang progresif. Maka karyawan tersebut diharapkan akan berubah, dan jika tidak berubah memungkinkan untuk dikeluarkan dari perusahaan atau di PHK (pemutusan hubungan kerja) (Fahmi, 2017:76).

Berdasarkan latar belakang, maka penulis mencoba untuk merumuskan pokok permasalahan dalam penelitian ini sebagai berikut:

1. Apakah penurunan jabatan berpengaruh terhadap kinerja karyawan pada Divisi Collection PT. Summit Oto Finance Pekanbaru?

2. Apakah pemindahan posisi berpengaruh terhadap kinerja karyawan pada Divisi Collection PT. Summit Oto Finance Pekanbaru?

3. Apakah pemutusan hubungan kerja berpengaruh terhadap kinerja karyawan pada Divisi Collection PT. Summit Oto Finance Pekanbaru?

4. Apakah pengaduan kepada pihak berwajib berpengaruh terhadap kinerja karyawan pada Divisi Collection PT. Summit Oto Finance Pekanbaru?

5. Apakah penurunan jabatan, pemindahan posisi, pemutusan hubungan kerja dan pangaduan kepada pihak berwajib ber- 
pengaruh terhadap kinerja karyawan pada Divisi Collection PT. Summit Oto Finance Pekanbaru?

Ada beberapa tujuan yang ingin dicapai melalui penelitian ini. Tujuan pertama adalah untuk membuktikan adanya pengaruh penurunan jabatan terhadap kinerja karyawan pada Divisi Collection PT. Summit Oto Finance Pekanbaru. Tujuan kedua adalah untuk membuktikan adanya pengaruh pemindahan posisi terhadap kinerja karyawan pada Divisi Collection PT. Summit Oto Finance Pekanbaru. Tujuan ketiga adalah untuk membuktikan adanya pengaruh pemutusan hubungan kerja terhadap kinerja karyawan pada Divisi Collection PT. Summit Oto Finance Pekanbaru. Tujuan keempat adalah untuk membuktikan adanya pengaruh pengaduan kepada pihak berwajib terhadap kinerja karyawan pada Divisi Collection PT. Summit Oto Finance Pekanbaru. Tujuan terakhir adalah untuk membuktikan adanya pengaruh penurunan jabatan, pemindahan posisi, pemutusan hubungan kerja dan pangaduan kepada pihak berwajib terhadap kinerja karyawan pada Divisi Collection PT. Summit Oto Finance Pekanbaru.

\section{Definisi Disiplin}

Afandi (2018:11) menyatakan bahwa pengertian disiplin kerja adalah suatu tata tertib atau peraturan yang dibuat oleh manajemen suatu organisasi, disyahkan oleh dewan komisaris atau pemilik modal, disepakati oleh serikat pekerja dan diketahui oleh Dinas Tenaga Kerja seterusnya orangorang yang tergabung dalam organisasi tunduk pada tata tertib yang ada dengan rasa senang hati, sehingga tercipta dan terbentuk melalui proses dari serangkaian perilaku yang menunjukkan nilai-nilai ketaatan, kepatuhan, keteraturan, dan ketertiban. Karena sudah menyatu dengan dirinya, maka sikap atau perbuatan yang dilakukan bukan lagi atau sama sekali tidak dirasakan sebagai beban, bahkan sebaliknya akan membebani dirinya bilamana ia tidak berbuat sebagaimana lazimnya.
Nilai-nilai kepatuhan telah menjadi bagian dari perilaku dalam kehidupannya. Sikap dan perilaku yang demikian tercipta melalui proses binaan melalui keluarga, Pendidikan, dan pengalaman atau pengenalan dari keteladanan dari lingkungannya. Disiplin akan membuat dirinya tahu membedakan halhal apa yang seharusnya dilakukan yang wajib dilakukan, yang noleh dilakukan, yang tak sepatutnya dilakukan (karena merupakan hal-hal yang dilarang).

Disiplin pada dasarnya merupakan tindakan manajemen untuk mendorong agar para anggota organisasi dapat memenuhi berbagai ketentuan serta peraturan yang berlaku di dalam suatu organisasi, yang mencakup seperti:

1. Adanya tata tertib atau ketentuanketentuan.

2. Adanya kepatuhan para pengikut.

3. Adanya sanki bagi pelanggar.

\section{Pendekatan Disiplin Kerja}

Afandi (2018:19) menyebutkan bahwa pendekatan disiplin kerja dibagi menjadi tiga, yaitu:

a. Pendekatan disiplin modern

b. Pendekatan disiplin tradisional

c. Pendekatan disiplin bertujuan

Pendekatan disiplin modern yaitu mempertemukan sejumlah keperluan atau kebutuhan baru diluar hukuman. Pendekatan disiplin modern berasumsi bahwa disiplin modern merupakan suatu cara menghindarkan bentuk hukuman secara fisik melindungi tuduhan yang benar untuk diteruskan pada proses hukum yang berlaku, keputusankeputusan yang semuanya terhadap kesalahan atau prasangka harus diperbaiki dengan mengadakan proses penyuluhan dengan mendapatkan fakta-faktanya, serta melakukan protes terhadap keputusan yang berat sebelah pihak terhadap kasus disiplin.

Pendekatan disiplin tradisional yaitu pendekatan disiplin dengan cara memberikan hukuman. Pendekatan ini berasumsi bahwa disiplin dilakukan oleh atasan kepada bawahan, dan tidak pernah ada peninjauan 
kembali bila telah diputuskan. Disiplin adalah hukuman untuk pelanggaran pelaksanaannya haruslah disesuaikan dengan tingkat pelanggarannya, pengaruh hukaman untuk memberi pelajaran kepada pelanggar maupun kepada karyawan lainnya, peningkatan perbuatan pelanggaran diperlukan hukuman yang lebih keras, serta pemberian hukuman terhadap karyawan yang melanggar kedua kalinya harus diberi hukuman yang berat.

Pendekatan disiplin bertujuan adanya pendekatan disiplin dengan cara memberikan hukuman. Pendekatan ini berasumsi bahwa disiplin kerja harus dapat diterima dan pahami oleh semua karyawan, disiplin bukanlah suatu hukuman tetapi merupakan pembentukan perilaku, serta bertujuan agar karyawan bertanggung jawab terhadap perbuatannya.

\section{Faktor yang Mempengaruhi Disiplin Kerja}

Faktor-faktor yang turut mempengaruhi disiplin kerja pegawai menurut Sutrisno (2015:89) adalah:

1. Besar kecilnya pemberian kompensasi.

2. Ada tidaknya keteladanan pimpinan dalam perusahaan.

3. Ada tidaknya aturan pasti yang dapat dijadikan pegangan.

4. Keberanian pimpinan dalam mengambil tindakan.

5. Ada tidaknya pengawasan pimpinan.

6. Ada tidaknya perhatian kepada para pegawai.

Ada dua jenis disiplin yang digunakan pada semua organisasi, yaitu (Nurmansyah, 2014:253):

a. Disiplin preventif adalah tindakan dimana manajemen mendorong karyawan untuk menuruti standar ukuran maupun aturanaturan sehingga pelanggaran bisa dicegah. Tujuannya adalah mengadakan disiplin pribadi setiap karyawan sehingga dapat menunjukkan derajat kedisiplinan yang diinginkan oleh organisasi agar tidak sampai jatuh pada hukuman (sanksi).

b. Disiplin korektif adalah tindakan yang harus menuruti aturan-aturan, dan jika melanggar atau memperkecil pelanggaran yang lebih lanjut, sehingga pada masa mendatang terpenuhilah standar-standar tersebut secara khusus, tindakan korektif merupakan hasil akhir dari beberapa tipe yang disebut disciplinary action (tindakan disiplin). Misalnya peringatan atau skorsing.

\section{Tujuan Disiplin Kerja}

Disiplin yang baik mencerminkan besarnya tanggung jawab seseorang terhadap tugas-tugas yang diberikan kepadanya. Karena hal ini akan mendorong gairah atau semangat kerja, dan mendorong terwujudnya tujuan organisasi.

Pegawai dengan semangat yang tinggi memberikan sikap positif, seperti kesetian, kegembiraan, kerjasama, kebanggaan dalam dinas dan ketaatan dengan kewajiban. Produktivitas dan efisiensi yang tinggi cenderung merupakan sikap-sikap dan tindakan-tindakan demikian. Sikap serta tindakan itu diantaranya disiplin. Disiplin termasuk dalam sikap mental pegawai. Yang dimaksud dalam sikap mental adalah sikap terhadap kerja itu sendiri, terhadap bekerja dalam industri, terhadap perlunya menghasilkan produk bermutu, terhadap pelayanan prima kepada pelanggan dan akhirnya terhadap integritas moral dan reputasi (Afandi, 2018:12).

\section{Bentuk Sanki dari Tindakan Indisipliner}

Fahmi (2016:75) mengemukakan ada beberapa bentuk tindakan sanki yang diterima oleh seorang karyawan akibat tindakan indisipliner yang dilakukannya, yaitu:
a. Teguran lisan

b. Teguran tertulis

Bentuk isi teguran tersebut teraplikasi dalam berbagai macam bentuk, dan secara umum berbentuk sebagai berikut:

1. Penuruan jabatan,

2. Pemindahan posisi,

3. Pemutusan hubungan kerja, atau

4. Pengaduan kepada pihak berwajib. 


\section{Dimensi dan Indikator Disiplin Kerja}

Dimensi dan indikator disiplin kerja dapat dilaksanakan oleh semua anggota atau pegawai yang bekerja pada suatu organisasi, adalah dimensi ketaatan waktu serta dimensi tanggungjawab kerja (Afandi, 2018:21). Dimensi ketaatan waktu memiliki indikator:

1. Masuk kerja tepat waktu.

2. Penggunaan waktu secara efektif.

3. Tidak pernah mangkir/tidak kerja.

Selanjutnya, dimensi tanggung jawab kerja memiliki dengan indikator:

1. Mematuhi semua peraturan organisasi atau perusahaan.

2. Target pekerjaan.

3. Membuat laporan kerja harian.

\section{Fungsi Kedisiplinan Kerja}

Afandi (2018:13) menyatakan bahwa disiplin kerja sangat dibutuhkan oleh setiap pegawai, disiplin menjadi persyaratan bagi pembentukan sikap, perilaku, dan tata kehidupan berdisiplin yang akan membuat para pegawai mendapat kemudahan dalam bekerja, dengan begitu akan menciptakan suasana kerja yang kondusif dan mendukung usaha pencapaian tujuan. Fungsi disiplin antara lain:

a. Menata kehidupan bersama dalam suatu organisasi.

b. Membangun dan melatih kepribadian yang baik.

c. Pemaksaan untuk mengikuti aturan organisasi.

d. Sanksi atau hukuman bagi yang melanggar disiplin.

Disiplin berfungsi mengatur kehidupan bersama, dalam suatu kelompok tertentu atau dalam dalam masyarakat. Dengan begitu, hubungan yang terjalin antara individu satu dengan individu lain menjadi lebih baik dan lancar.

Disiplin juga dapat membangun kepribadian seseorang pegawai lingkungan yang memiliki disiplin yang baik, sangat berpengaruh pada kepribadian seseorang. Lingkungan organisasi yang memiliki keadaan yang tenang, tertib dan tentram sangat berperan dalam upaya membangun kepribadian yang baik.

Disiplin merupakan sarana untuk melatih kepribadian pegawai agar senantiasa menunjukan kinerja yang baik sikap, perilaku dan pola kehidupan yang baik dan berdisiplin tidak terbentuk dalam waktu yang lama, salah satu proses untuk membentuk kepribadian tersebut dilakukan melalui proses latihan.

Disiplin berfungsi sebagai pemaksaan terhadap seseorang untuk rela mengikuti peraturan-peraturan yang berlaku di dalam lingkungan tersebut dengan pemaksaan, pembiasaan dan latihan disiplin seperti itu dapat menyadarkan bahwa disiplin itu penting.

Pada awalnya mungkin disiplin itu berat karena suatu pemaksaan, namun karena adanya pembiasaan dan proses latihan yang terus-menerus maka disiplin dilakukan atas kesadaran dalam diri sendiri dan dirasakan sebagai kebutuhan dan kebiasaan. Diharapkan utuk dikemudian hari, disiplin ini meningkat menjadi kebiasaan berfikir baik, positif bermakna dan memandang jauh kedepan disiplin bukan hanya soal mengikuti dan mentaati peraturan, melainkan sudah meningkat menjadi disiplin berfikir yang mengatur dan mempengaruhi seluruh aspek kehidupannya.

Disiplin yang disertai ancaman sanksi atau hukuman sangat penting karena dapat memberikan dorongan kekuatan untuk mentaati dan mematuhinya tanpa ancaman, sanksi atau hukuman, dorongan ketaatan dan kepatuhan dapat menjadi lemah serta motivasi untuk mengikuti aturan yang berlaku menjadi kurang.

\section{Pentingnya Disiplin Kerja}

Mulyadi (2015:52) mengemukakan disiplin adalah salah satu cara untuk memelihara keteraturan dan peningkatan disiplin. Tujuan utama dalam melaksanakan kedisiplinan kerja adalah untuk meningkatkan efisiensi, dan meningkatkan produktivitas, serta mengurangi pemborosan baik waktu maupun energi. Disamping untuk mencegah pemborosan, juga untuk mencegah kerusakan 
dan kehilangan barang, dan kelengkapan kerja diakibatkan oleh ketidakdisiplinan dalam bekerja. Displin juga bisa untuk mengatasi kesalahan kerja dan keteledoran dalam melaksanakan pekerja yang disebabkan karena kurang hati-hati dalam melaksanakan pekerjaan.

Disiplin juga untuk melatih bagi karyawan atau pekerja untuk tidak terlambat dalam melakaksana tugasnya dan terlalu cepat meninggalkan pekerjaan. Hal ini semuanya disebabkan karena kemalasan seorang karyawan. Disiplin kerja juga bisa disebakan karena salah penafsiran atau salah pengertian sehingga timbul rasa malas, segan untuk bekerja dan lain sebagainya.

Mengingat sifat manusia yang tidak sempurna, maka program perusahaan salah satunya adalah disiplin kerja, itu harus diutamakan dan selalu digiatkan serta ditegakan, dengan demikian seorang karyawan akan mudah untuk mencapai tujuan perusahaan maupun tujuan pribadi karena melaksanakan dan menjalankan apa yang menjadi tugasnya dengan disiplin. Dengan demikian, disiplin kerja sangat dibutuhkan untuk menunjang dan kelancaran semua aktivitas perusahaan atau organisasi, agar tujuan organisasi/perusahaan dapat dicapai dengan cepat dan tepat.

Disiplin kerja dapat dilihat sebagai suatu sesuatu yang besar manfaatnya, baik bagi kepentingan organisasi maupun secara individu oleh karyawan. Bagi organisasi atau perusahaan, adanya disiplin kerja akan menjamin pemeliharaan tata tertib dan kelancaran pelaksanaan tugas, sehingga diperoleh hasil yang optimal. Adapun bagi karyawan akan diperoleh suasana kerja yang menyenangkan sehingga akan bisa menambah semangat kerja di dalam melaksanakan pekerjaannya. Dengan demikian, karyawan dapat melaksanakan tugasnya dengan penuh kesadaran serta dapat mengembangkan tenaga dan pikirannya semaksimal mungkin demi terwujudnya tujuan organisasi.

Sikap ketidakdisiplinan dan kedisiplinan dapat menjadi panutan orang lain. Jika lingkungan kerja semua disiplin, maka seorang karyawan atau pekerja akan ikut disiplin. Tetapi jika lingkungan kerja tidak disiplin, maka seorang pegawai juga akan ikut tidak disiplin. Untuk itu sangat sulit bagi lingkungan kerja yang tidak disiplin tetapi ingin menerapkan disiplin pegawai, karena lingkungan kerja akan menjadi panutan bagi para pegawai.

\section{Tujuan Rotasi Pekerjaan}

Menurut Fahmi (2017:93), dilakukannya rotasi pekerjaan tentunya ini bukan tanpa tujuan yang jelas, namun memiliki maksud yang jelas dan tujuan yang jelas. Maka secara umum ada beberapa tujuan mengapa rotasi pekerjaan tersebut dilakukan, yaitu:

a. Membangun penguasan ilmu yang lebih dalam pada setiap divisi perusahaan secara penuh.

b. Membangun hubungan yang lebih akrab dengan setiap karyawan di berbagai divisi yang ikut merasakan rotasi pekerjaan tersebut.

c. Membangun konsep aplikasi kaderisasi pada calon pemimpin secara aplikatif dan teratur.

d. Memberikan pembuktian kepada para karyawan pemilihan pemimpinan dilakukan dengan cara yang sangat adil tanpa ada factor bersifat tiba-tiba akan tetapi melalui proses yang Panjang dan yang bersangkutan telah menunjukkan kompetensinya pada saat ia ditugaskan diberbagai divisi.

\section{Rotasi Pekerjaan Mengindari Korupsi, Kolusi, dan Nepotisme}

Sering orang mendiskusikan berbagai dampak dari rotasi secara jangka Panjang. Bahwa memang ada banyak dampak positif penerapan rotasi secara jangka Panjang bagi manajemen perusahaan. Salah satu dampak positif rotasi adalah mampu menghindari timbulnya korupsi, kolusi, dan nepotieme.

Ketika seseorang duduk pada suatu jabatan terlalu lama dan ia telah begitu mahir menguasai pekerjaan tersebut hingga berbagai seluk beluknya serta telah terbentuk jaringan eksternal dengan sangat baik maka jika karyawan tersebut memiliki niat tidak baik 
memungkin ia melakukan tindakan korupsi, kolusi dan nepotisme.

Fraud (kecurungan) merupakan suatu tindakan yang dilakukan secara disengaja dan itu dilakukan untuk tujuan pribadi atau kelompok dimana tindakan yang disengaja tersebut telah menyebabkan kerugian pihak tertentu atau insitusi tertentu. Dalam kata fraud itu sendiri dapat diartikan dengan berbagai makna yang terkandung didalamnya seperti:

1. Kecurangan

2. Kebohongan

3. Penipuan

4. Kejahatan

5. Penggelapan barang-barang

6. Manipulasi data-data

7. Rekayasa informasi

8. Mengubah opini dengan pemutarbalikan fakta yang ada

9. Menghilangkan barang bukti secara sengaja

Sehingga jika kita menarik berbagai kesimpulan dari pendapat tersebut bahwa tindakan fraud (kecurangan) itu merupakan sesuatu yang disebabkan oleh keinginan seseorang yang teraplikasi dalam bentuk perilakunya untuk melakukan suatu tindakan yang menyalahi aturan.

Atas dasar berbagai kondisi kejahatan yang mungkin bisa terjadi dan sudah menjadi kewajiban seorang manajer sumber daya manausia untuk mampu mengatasi masalah sebelum masalah itu terjadi, yaitu salah satunya dengan melakukan tindakan rotasi pekerjaan. Karena dengan rotasi pekerjaan karyawan diharapkan untuk selalu beradaptasi dengan lingkungan baru dan orang-orang baru tentunya yang jelas ia harus mulai membangun hubungan dan memahami karakteristik setiap orang dari baru kembali.

\section{Definisi Kinerja}

Afandi (2018:83) menyatakan bahwa kinerja apabila dikaitkan dengan performance sebagai kata benda (noun), maka pengertian performance atau kinerja adalah hasil kerja yang dapat dicapai oleh seseorang atau kelompok orang dalam suatu perusahaan sesuai dengan wewenang dan tanggung jawab masing-masing dalam upaya pencapaian tujuan perusahaan secara illegal, tidak melanggar hukum dan tidak bertentangan dengan moral dan etika.

Performansi adalah catatan yang dihasilkan dari fungsi suatu pekerjaan tertentu atau kegiatan selama periode waktu tertentu. Kimerja pegawai didefinisikan sebagai kemampuan pegawai dalam melakukan sesuatu keahlian tertentu. Kinerja pegawai sangatlah perlu, sebab dengan kinerja ini akan diketahui seberapa jauh kemampuan pegawai dalam melaksanakan tugas yang dibebankan kepadanya. Untuk itu diperlukan penentuan kriteria yang jelas dan terukur serta ditetapkan secara bersama-sama yang dijadikan sebagai acuan.

Kinerja merupakan derajat penyusunan tugas yang mengatur pekerjaan seseorang. Jadi, kinerja adalah kesediaan seseorang atau kelompok orang untuk melakukan kegiatan atau menyempurnakannya sesuai dengan tanggung jawabnya dengan hasil seperti yang diharapkan. Kinerja adalah hasil yang dicapai oleh seseorang menurut ukuran yang berlaku untuk pekerjaan yang bersangkutan. Kinerja merupakan ekspresi potensi seseorang dalam memenuhi tanggung jawabnya dengan cara menetapkan standar tertentu. Kinerja merupakan salah satu kumpulan total dari kerja yang ada pada diri pekerja.

\section{Kriteria Kinerja}

Kriteria kinerja adalah dimensi-dimensi pengevaluasian kinerja seseorang pemegang jabatan, suatu tim, dan suatu unit kerja. Secara bersama-sama dimensi itu merupakan harapan kinerja yang berusaha dipenuhi individu dan tim guna mencapai strategi organisasi. Ada 3 (tiga) jenis dasar kriteria kinerja, yaitu:

1. Kriteria berdasarkan sifat memusatkan diri pada karakteristik pribadi seseorang karyawan. Loyalitas, keandalan, kemampuan berkomunisasi, dan keterampilam memimpin meruapakan sifat-sifat yang sering dinilai selama proses penilaian. 
Jenis kriteria ini memusatkan diri pada bagaimana seseorang, bukan apa yang dicapai atau tidak dicapai seseorang dalam pekerjaannya.

2. Kriteria berdasarkan perilaku terfokus pada bagaimana pekerjaan dilaksanakan. Kriteria semacam ini penting sekali bagi pekerjaan yang membutuhkan hubungan antar personal. Sebagai contoh apakah SDM nya ramah atau menyenanglan.

3. Kriteria berdasarkan hasil, kriteria ini semakin popular dengan makin ditekannya produktivitas serta daya saing internasional. Kriteria ini berfokus pada apa yang telah dicapai atau dihasilkan kerimbang bagaimana sesuatu dicapai atau dihasilkan.

\section{Faktor yang Mempengaruhi Kinerja}

Faktor-faktor yang dinilai berpengaruh terhadap kinerja adalah:

a. Kemampuan, kepribadian dan minat kerja.

b. Kejelasan dan penerimaan atau kejelesan peran seseorang pekerja yang merupakan taraf dari pengertian dan penerimaan seseorang atas tugas yang diberikan kepadanya.

c. Tingkat motivasi pekerja yaitu daya energi yang mendorong, mengarahkan dan mempertahankan perilaku.

d. Kompetensi yaitu keterampilan yang dimiliki seseorang pegawai.

e. Fasilitas kerja yaitu seperangkat alat pendukung kelancaran dari operasional perusahaan.

f. Budaya kerja yaitu perilaku kerja pegawai yang kreatif dan inovatif.

g. Kepemimpinan yaitu perilaku pemimpin dalam mengarahkan pegawai dalam bekerja.

h. Disiplin kerja yaitu aturan yang dibuat oleh perusahaan agar semua pegawai ikut mematuhinya agar tujuan tercapai.

\section{Penilaian Kinerja}

Afandi (2018:87) mengatakan bahwa pada prinsipnya penilaian kinerja adalah merupakan cara pengukuran kontribusikontribusi dari individu dalam instansi yang dilakukan terhadap organisasi. Nilai penting dari penilaian kinerja adalah menyangkut penentuan tingkat kontribusi individua atau kinerja yang diekspresikan dalam proses penyelesaian tugas-tugas yang menjadi tanggungjawabnya. Penilaian kinerja intinya adalah untuk mengertahui seberapa produktif seorang karyawan dan apakah ia bias berkinerja sama atau lebih efektif pada masa yang akan datang, sehingga karyawan, organisasi maupun masyarkat memperoleh manfaat.

Tujuan penilaian kinerja terdapat pendekatan ganda terhadap tujuan penilaian prestasi kerja sebagai berikut:

1. Tujuan evaluasi hasil-hasil penilaian prestasi kerja digunakan sebagai dasar bagi evaluasi regular terhadap prestasi para anggota organisasi, yang meliputi:

a. Telaah gaji, keputusan-keputusan kompensasi yang mencakup kenaikan merit-pay, bonus dan kenaikan gaji lainnya merupakan salah satu tujuan utama penilaian prestasi kerja.

b. Kesempatan promosi, keputusankeputusan terkait penyusunan pegawai (staffing) yang berkenaan dengan promosi, demosi, tranfer dan pemberhentian karyawan merupakan tujuan dari penilian preatasi kerja.

2. Tujuan pengembangan, yang meliputi:

a. Informasi yang dihasilkan oleh sistem penilaian prestasi kerja dapat digunakan untuk mengembangkan pribadi anggota-anggota organisasi.

b. Mengukuhkan dan menopang prestasi kerja. Umpan balik prestasi kerja (performance feedback) merupakan kebutuhan pengembangan yang utama karena hampir semua karyawan ingin mengetahui hasil penilaian yang dilakukan.

c. Meningkatkan prestasi kerja. Tujuan penilaian prestasi kerja juga untuk memberikan pedoman kepada karyawan bagi peningkatan prestasi kerja di masa yang akan datang. 
d. Menentukan tujuan-tujuan progress karir. Penilaian prestasi kerja akan memberikan informasi pada karyawan yang dapat digunkan sebagai dasar pembahasan tujuan dan rencana karir jangka panjang.

e. Penentukan kebutuhan-kebutuhan pelatihan. Penilian prestasi kerja individu dapat memaparkan kumpulan data untuk digunakan sebagai sumber analisis dan identifikasi kebutuhan pelatihan.

\section{Dimensi dan Indikator Kinerja} adalah:

Dimensi dan indikator dari kinerja

1. Dimensi hasil kerja yang terdiri dari tiga indikator, yaitu:
a. Kuantitas hasil kerja.
b. Kualitas hasil kerja.
c. Efisiensi dalam melaksanakan tugas.

2. Perilaku yang terdiri dari tiga indikator, yaitu:
a. Disiplin kerja.
b. Insiatif.
c. Ketelitian.

3. Sifat pribadi yang terdiri dari tiga indikator, yaitu:
a. Kepemimpinan.
b. Kejujuran.
c. Kreativitas.

\section{Penelitian Terdahulu}

Hasil penelitian milik Bachtiar (2018) menunjukkan bahwa disiplin kerja memiliki pengaruh positif dan signifikan terhadap kinerja karyawan dengan kontribusi pengaruh sebesar 60,8\%, sedangkan sisanya sebesar $39,2 \%$ dipengaruhi faktor lain. Pengujian hipotesis diperoleh t-hitung $>\mathrm{t}$-tabel $(12,329$ $>1,984)$, dan hal itu konsisten dengan nilai probability signification $<0,05$. Dengan demikian, $\mathrm{H}_{0}$ ditolak dan $\mathrm{H}_{1}$ diterima artinya terdapat pengaruh yang positif dan signifikan antara disiplin kerja terhadap kinerja karyawan.
Purnomo dkk. (2017) menunjukkan berdasarkan hasil analisis bahwa motivasi kerja dan disiplin kerja berpengaruh secara simultan terhadap kinerja karyawan sebesar $32,6 \%$; sedangkan sisanya sebesar $67,4 \%$ dipengaruhi oleh variabel lain yang tidak diteliti dalam penelitian ini. Motivasi kerja berpengaruh secara parsial dengan nilai signifikan $(0,011)$ lebih kecil dari $\alpha(0,050)$. Sedangkan disiplin kerja juga berpengaruh secara parsial dengan nilai 0,034 lebih kecil dari $\alpha(0,050)$. Maka diharapkan PT Tentrem Sejahtera untuk selalu meningkatkan motivasi kerja dan disiplin kerja agar kinerja karyawan lebih memuaskan.

Hasil penelitian Darmanto (2015) menunjukkan bahwa motivasi berpengaruh nyata terhadap kinerja pegawai lingkungan Balai Besar KSDA Sumatera Utara. Besaran pengaruh motivasi terhadap kinerja pegawai adalah sebesar $36,48 \%$, sedangkan sisanya $63,52 \%$ ditentukan oleh faktor lain. Disiplin kerja berpengaruh nyata terhadap kinerja pegawai lingkungan Balai Besar KSDA Sumatera Utara. Besaran pengaruh disiplin kerja terhadap kinerja pegawai adalah sebesar $15,22 \%$, sedangkan sisanya sebesar $84,78 \%$ ditentukan oleh faktor lain. Motivasi dan disiplin kerja secara bersama-sama memiliki pengaruh terhadap kinerja pegawai dalam lingkungan Balai Besar KSDA Sumatera Utara. Besaran pengaruh motivasi dan disiplin kerja secara bersama-sama terhadap kinerja pegawai adalah sebesar $36,68 \%$, sedangkan sisanya $63,32 \%$ ditentukan oleh faktor-faktor lainnya.

Agung (2013) dalam hasil penelitiannya memperoleh bahwa kedisiplinan kerja tidak berpengaruh terhadap kinerja, lingkungan kerja tidak berpengaruh terhadap kinerja, budaya kerja berpengaruh positif terhadap kinerja tenaga pengajar, dan secara bersamasama kedisiplinan kerja, lingkungan kerja dan budaya kerja berpengaruh positif terhadap kinerja tenaga pengajar. 

Tindakan Indisipliner, yaitu:
1. Penurunan Jabatan
2. Pemindahan Posisi
3. Pemutusan Hubungan Kerja
4. Pengaduan Kepada Pihak Berwajib

\section{Gambar 1. Model Penelitian}

\section{Hipotesis}

Hipotesis adalah pernyataan mengenai sesuatu hal yang harus diuji kebenarannya. Berdasarkan pada landasan teori dan kerangka pemikiran tersebut di atas, hipotesis yang diajukan dalam penelitian ini adalah sebagai berikut:

1. Penurunan jabatan berpengaruh terhadap kinerja karyawan pada Divisi Collection PT. Summit Oto Finance Pekanbaru.

2. Pemindahan posisi berpengaruh terhadap kinerja karyawan pada Divisi Collection PT. Summit Oto Finance Pekanbaru.

3. Pemutusan hubungan kerja berpengaruh terhadap kinerja karyawan pada Divisi Collection PT. Summit Oto Finance Pekanbaru.

4. Pengaduan kepada pihak berwajib berpengaruh terhadap kinerja karyawan pada Divisi Collection PT. Summit Oto Finance Pekanbaru.

5. Penurunan jabatan, pemindahan posisi, pemutusan hubungan kerja dan pangaduan kepada pihak berwajib berpengaruh terhadap kinerja karyawan pada Divisi Collection PT. Summit Oto Finance Pekanbaru.

\section{METODE PENELITIAN}

Populasi dan sampel dari penelitian ini adalah seluruh karyawan pada divisi collection PT. Summit Oto Finance Pekanbaru, yaitu sebanyak 42 orang. Dengan demikian, jumlah responden adalah sebanyak 42 orang, dengan teknik sensus.

\section{Definisi Operasional Variabel}

Untuk menentukan nilai atau skor tindakan indisipliner atas kinerja karyawan maka perlu kiranya diberikan penjelasan mengenai definisi dari variabel penelitian, item pernyataan (indikator), skala pengukuran indikator, dan interval kelas rata-rata dari total variabel yang dijawab oleh responden.

Untuk skala pengukuran indikator, peneliti menggunakan 5 (lima) alternatif pilihan pernyataan dalam bentuk skala likert. Sedangkan untuk interval kelas rata-rata, total variabel diperoleh dari total skor pernyataan dengan cara menjumlahkan nilai-nilai bobot dari indikator dan dibagi jumlah indikator variabel. Mengenai skala pengukuran indikator dan interval kelas rata-rata total variabel akan dijelaskan pada bagian teknik analisis data.

\section{Teknik Analisis Data}

Teknik analisis yang dipakai dalam penelitian ini adalah analisis statistik deskriptif dan infensial. Untuk lebih jelasnya analisis tersebut dapat diperhatikan langkahlangkah sebagai berikut:

1. Analisis Statistik Deskriptif.

Dalam hal ini analisis deskriptif untuk memberikan gambaran tentang perolehan bobot dari item pertanyaan, nilai interval kelas rata-rata jumlah tanggapan responden terhadap item pertanyaan, dan nilai rata-rata total variabel.

\section{Analisis Statistik Inferensial}

Analisis statistik inferensial digunakan untuk menguji hipotesis yang sudah dirumuskan. Namun sebelum pengujian hipotesis tersebut dilakukan terlebih dahulu beberapa persyaratan pengujian asumsi klasik, yaitu uji normalitas, heteroskedastisitas, dan autokorelasi. Apabila pengujian tersebut lolos dari asumsi klasik maka dilanjutkan pengujian 
hipotesis menggunakan analisis regresi linear berganda.

3. Uji Asumsi Klasik

a. Uji Normalitas

Sunyoto (2013:90) menyatakan dalam menentukan data berdistribusi normal ataupun tidak, cukup membandingkan antara dara riil atau nya dengan garis kurva yang berbentuk, apakah mendekati normal atau memang normal sana sekali, jika data riil membentuk garis kurva cenderung tidak simetri terhadap mean (U), maka dapat dikatakan data berdistribusi tidak normal dan sebaliknya.

b. Uji Heteroskedastisitas

Sunyoto (2013:90) menyatakan dalam persamaan regresi berganda perlu juga diuji mengenai sama atau tidak varian dari residual dari observasi yang satu dengan observasi yang lain. Jika residualnya memiliki varian yang sama maka disebut homoskedastisitas, dan jika variannya tidak sama atau berbeda maka disebut heterokedastisitas. Persamaan regresi yang baik adalah jika tidak terjadi heterokedastisitas.

c. Uji Multikolinearitas

Sunyoto (2013:87) menyatakan uji asumsi klasik jenis ini diterapkan untuk analisis regresi berganda yang teridir dari dua atau lebih variabel bebas ataupun independen variabel $\left(\mathrm{X}_{1,2,3, \ldots \mathrm{n}}\right)$ yang mana akan diukur keeratan hubungan antar variabel bebas itu melalui besaran koefisien kolerasi (r).

d. Uji Autokolerasi

Sunyoto (2013:97) menyatakan persamaan regresi yang baik adalah tidak memiliki masalah autokolerasi, jika terjadi autokolerasi maka persamaan tersebut menjadi tidak baik atau tidak layak dipakai prediksi. Masalah autokolerasi baru timbul jika adanya kolerasi secara linier antara kesalahan pengganggu dari periode $t$ (saat ini) dan kesalahan pengganggu periode $\mathrm{t}-1$ (sebelumnya).

\section{Pengujian Hipotesis}

Sekaran (2007:162) berargumen bahwa studi yang termasuk dalam pengujian hipotesis biasanya menjelaskan sifat hubungan tertentu, ataupun menentukan perbedaan antar kelompok atau kebebasan (independensi) dua atau lebih faktor dalam suatu situasi. Pengujian hipotesis dapat dibedakan antara pengujian secara simultan dan pengujian secara parsial.

1. Pengujian Secara Simultan

Pengujian regresi secara simultan yaitu untuk melihat besarnya pengaruh variabel bebas secara simultan terhadap variabel terikat, serta menggunakan uji koefisien determinasi $\left(\mathrm{R}^{2}\right)$. Koefisien determinasi $\left(\mathrm{R}^{2}\right)$ ini bernilai antara 0 dengan $1\left(0 \leq \mathrm{R}^{2} \leq 1\right)$ untuk mengukur ketepatan garis yang dipandangkan (garis regresi) yang didapati dari Xi dan Y.

\section{Pengujian Secara Parsial}

Untuk membuktikan menggunakan analisi regresi berganda dengan formulasi sebagai berikut:

$$
Y_{i}=b_{0}+b_{1} X_{1 i}+b_{2} X_{2 i}+\ldots+b_{k} X_{k i}+e
$$

Dari formulasi tersebut di atas maka untuk penelitian ini dapat diturunkan rumus sebagai berikut:

$$
Y_{i}=b_{0}+b_{1} X_{1}+b_{2} X_{2}+e
$$

dimana:

$\mathrm{Y}=$ Kinerja

$\mathrm{X}_{1}=$ Penurunan Jabatan

$\mathrm{X}_{2}=$ Pemindahan Posisi

$\mathrm{X}_{3}=$ Pemutusan Hubungan Kerja

$\mathrm{X}_{4}=$ Pengaduan kepada Pihak Berwajib

$\mathrm{b}_{0}=$ Konstanta

$\mathrm{b}_{1}, \mathrm{~b}_{2}=$ Koefisien regresi dari variabel $\mathrm{Xi}$

$\mathrm{e} \quad=$ Kesalahan pengganggu

Koefisien Determinasi $\left(\mathbf{R}^{\mathbf{2}}\right)$

Ghozali (2016:95) menyatakan bahwa koefisien determinasi $\left(\mathrm{R}^{2}\right)$ pada intinya mengukur seberapa jauh kemampuan model 
dalam menerangkan variasi variabel dependen. Nilai koefisien determinasi adalah antara nol dan satu. Nilai $\mathrm{R}^{2}$ yang kecil berarti kemampuan variabel-variabel independen dalam menjelaskan variasi dependen amat terbatas.

\section{HASIL ANALISIS \\ Analisis Statistik Deskriptif}

Analisis deskriftif menurut Sugiyono (2012:147) adalah untuk menganalisis data melalui cara-cara mendeskripsikan atau menggambarkan data yang telah terkumpul sebagaimana adanya tanpa bermaksud membuat kesimpulan yang berlaku untuk umum atau generalisasi.

\section{Uji Validitas}

Riduwan (2010:73) menjelaskan bahwa validitas merupakan suatu ukuran yang menunjukkan tingkat keandalan ataupun kesahihan suatu alat ukur. Alat ukur yang kurang valid berarti memiliki validitas rendah. Untuk menguji validitas alat ukur, terlebih dahulu dicari harga korelasi antara bagian-bagian dari alat ukur dengan skor total yang merupakan jumlah tiap skor butir, untuk menghitung validitas alat ukur digunakan rumus Pearson Product Moment.

Tabel 1. Hasil Uji Validitas

\begin{tabular}{lccc}
\hline & $\begin{array}{c}\text { Scale Mean if Item } \\
\text { Deleted }\end{array}$ & $\begin{array}{c}\text { Scale Variance if } \\
\text { Item Deleted }\end{array}$ & $\begin{array}{c}\text { Corrected Item-Total } \\
\text { Correlation }\end{array}$ \\
\hline PJ & 79.4286 & 179.129 & .357 \\
PP & 80.2143 & 140.709 & .874 \\
PHK & 79.9524 & 120.973 & .850 \\
PKPB & 79.7143 & 140.794 & .905 \\
Kinerja & 76.3095 & 127.975 & .850 \\
\hline
\end{tabular}

Sumber: Data primer diolah, 2018

Tabel 2. Hasil Uji Reliabilitas

\begin{tabular}{lccc}
\hline & $\begin{array}{c}\text { Scale Mean if Item } \\
\text { Deleted }\end{array}$ & $\begin{array}{c}\text { Scale Variance if } \\
\text { Item Deleted }\end{array}$ & $\begin{array}{c}\text { Cronbach's Alpha if Item } \\
\text { Deleted }\end{array}$ \\
\hline PJ & 79.4286 & 179.129 & .949 \\
PP & 80.2143 & 140.709 & .856 \\
PHK & 79.9524 & 120.973 & .859 \\
PKPB & 79.7143 & 140.794 & .851 \\
Kinerja & 76.3095 & 127.975 & .857 \\
\hline
\end{tabular}

Sumber: Data primer diolah, 2018

Berdasarkan Tabel 1 diketahui bahwa nilai corrected item-total correlation (r-hit) dari hasil pengujian data yang diperoleh lebih besar dibandingkan 0.304 (r-tab). Dengan demikian, semua item pernyataan tersebut dinyatakan valid.

\section{Uji Reliabilitas}

Riduwan (2010:74-75) menyatakan uji reliabilitas dilakukan untuk mendapatkan tingkat ketepatan (keterandalan ataupun keajegan) alat pengumpul data (instrument) yang digunakan. Uji reliabilitas instrument dilakukan dengan rumus alpha. Kemudian diuji dengan uji instrument dilakukan dengan rumus Korelasi Pearson Product Moment.

Berdasarkan Tabel 2 dapat diketahui nilai alpha Cronbach's dari variabel citra merek, kualitas produk dan keputusan pembelian adalah lebih besar dari $\alpha$ standar (0.6) 


\section{Uji Normalitas}

Pengujian terhadap distribusi data yang dilakukan adalah menggunakan statistika non parametrik $\mathrm{Z}$ dari Kolmogorov-Smirnov dengan kriteria bahwa data dinyatakan berdistribusi normal apabila harga taraf signifikansi dari nilai Z Kolmogorov-Smirnov tersebut $>0,05$. Hasil pengujiannya dapat dilihat pada Tabel 3. Dari Tabel 3 bahwa semua variabel penelitian mempunyai data yang berdistribusi normal, karena taraf signifikansinya $>0$.

Tabel 3. Hasil Uji Normalitas Data

\begin{tabular}{clcc}
\hline No & \multicolumn{1}{c}{ Variabel } & Z.K.S & Signifikansi \\
\hline 1 & Penurunan Jabatan $\left(\mathrm{X}_{1}\right)$ & 1,157 & 0,138 \\
2 & Pemindahan Posisi $\left(\mathrm{X}_{2}\right)$ & 0,561 & 0,911 \\
3 & PHK $\left(\mathrm{X}_{3}\right)$ & 1,116 & 0,166 \\
4 & Pengaduan Kepada Pihak Berwajib $\left(\mathrm{X}_{4}\right)$ & 0,672 & 0,757 \\
5 & Kinerja Karyawan $(\mathrm{Y})$ & 0,947 & 0,331 \\
\hline
\end{tabular}

Sumber: Data primer diolah, 2018

Tabel 4. Hasil Uji Multikolinieritas Data

\begin{tabular}{clc}
\hline No & \multicolumn{1}{c}{ Variabel } & VIF \\
\hline 1 & Penurunan Jabatan $\left(\mathrm{X}_{1}\right)$ & 1,399 \\
2 & Pemindahan Posisi $\left(\mathrm{X}_{2}\right)$ & 6,216 \\
3 & PHK $\left(\mathrm{X}_{3}\right)$ & 2,905 \\
4 & Pengaduan Kepada Pihak Berwajib $\left(\mathrm{X}_{4}\right)$ & 7,748 \\
\hline
\end{tabular}

Sumber: Data primer diolah, 2018

Tabel 5. Hasil Uji Normalitas Data

\begin{tabular}{clcc}
\hline No & \multicolumn{1}{c}{ Variabel } & Rank Spearman Correlation & Signifikansi \\
\hline 1 & Penurunan Jabatan $\left(\mathrm{X}_{1}\right)$ & $-0,024$ & 0,882 \\
2 & Pemindahan Posisi $\left(\mathrm{X}_{2}\right)$ & $-0,033$ & 0,836 \\
3 & PHK $\left(\mathrm{X}_{3}\right)$ & 0,005 & 0,973 \\
4 & Pengaduan Kepada Pihak Berwajib $\left(\mathrm{X}_{4}\right)$ & $-0,007$ & 0,965 \\
5 & Kinerja Karyawan $(\mathrm{Y})$ & 0,320 & 0,139 \\
\hline
\end{tabular}

Sumber: Data primer diolah, 2018

\section{Uji Multikolinieritas}

Pengujian ini bertujuan untuk menguji apakah model regresi ditemukan korelasi antar variabel bebas. Model regresi yang baik seharusnya tidak terjadi korelasi di antara variabel bebas. Suatu model regresi terbebas dari gejala multikolonieritas apabila harga Variance Inflation Factor (VIF) tak melebihi nilai 10. Hasil pengujian secara keseluruhan dapat dilihat pada Tabel 4. Dari Tabel 4 diperoleh bahwa semua variabel bebas mempunyai nilai VIF kurang dari 10. Dengan demikian, masing-masing variabel bebas tersebut tidak mengalami mutikolinieritas.

\section{Uji Heterokesdasitas}

Pengujian ini bertujuan menguji apakah dalam model regresi terjadi ketidaksamaan variasi dari residual data pengamatan yang satu ke data pengamatan yang lain. Jika variasi residual tetap maka dinyatakan bersifat homokedastisitas, dan jika berbeda maka dinyatakan bersifat heteroskedastisitas. Untuk mengetahui apakah model statistik mengalami problem heterokesdasitas, salah 
satu caranya dengan menggunakan metode Rank Spearman. Hasil perhitungan dapat dilihat pada Tabel 5.

Pada Tabel 5 menunjukkan bahwa hasil uji heterokesdastisitas bahwa semua variabel mempunyai tingkat signifikansi lebih dari 0.05, maka dapat disimpulkan bahwa semua variable terbebas dari heteroskesdastisitas.

\section{Uji Autokorelasi}

Pengujian ini bertujun menguji apakah persamaan regresi yang digunakan dalam studi ini memiliki masalah autokolerasi ataukah tidak. Masalah autokolerasi baru timbul jika adanya kolerasi secara linier antara kesalahan pengganggu dari periode $t$ (saat ini) dan kesalahan pengganggu periode t-1 (sebelumnya). Jika terjadi autokolerasi maka persamaan tersebut menjadi tidak baik atau tidak layak dipakai prediksi. Hasil perhitungan autokorelasi dapat dilihat pada Tabel 6.

Dari hasil Tabel 6, hasil uji autokolerasi tersebut diketahui bahwa nilai Durbin Watson (DW) maka nilainya sebesar 2.161 dengan pengambilan keputusan yaitu $\mathrm{dl}=1.3064$ dan $\mathrm{du}=1.7202$ sehingga $4-\mathrm{du}=4-1.7202=$ 2.279. Jadi keputusannya adalah 1.3064 < $2.103<2.279$ sehingga menunjukkan tidak terjadinya gejala autokolerasi.

Tabel 6. Hasil Uji Autokorelasi Data

\begin{tabular}{lcrrrr}
\multicolumn{2}{c}{ Model } & \multicolumn{2}{c}{ R } & R Square & \multicolumn{2}{c}{$\begin{array}{c}\text { Adjusted R } \\
\text { Square }\end{array}$} & $\begin{array}{c}\text { Std. Error of the } \\
\text { Estimate }\end{array}$ & Durbin-Watson \\
\hline 1 & $.945^{\mathrm{a}}$ & .893 & .882 & 1.31758 & 2.103 \\
\hline $\begin{array}{l}\text { a. Predictors: (Constant), PKPB, PJ, PHK, PP } \\
\text { b. Dependent Variable: Kinerja }\end{array}$ & & & & & \\
\hline
\end{tabular}

Sumber: Data primer diolah, 2018

\section{Uji Regresi Linier Berganda}

Selanjutnya dalam penelitian ini digunakan persamaan regresi melalui uji interaksi atau sering disebut dengan Multiple Regresion Analisys (MRA), yang merupakan aplikasi khusus regresi berganda linier dimana dalam persamaan regresinya mengandung unsur interkasi yang didapat dari selisih mutlak dari variabel independen.

Berdasarkan hasil pengujian pada Tabel 7 dapat dilihat bahwa besarnya koefisien determinasi $\left(\mathrm{R}^{2}\right)$ sebesar 0.882 yang berarti variabilitas variabel kinerja karyawan yang dapat dijelaskan oleh variabilitas variabelvariabel penurunan jabatan, pemindahan posisi, pemutusan hubungan kerja dan pengaduan kepada pihak berwajib, sebesar 0.822 atau $82.2 \%$.

Berdasarkan hasil penelitian diketahui bahwa semua hipotesis yang diajukan, dapat diterima dengan baik dan hasilnya sangat signifikan. Hasil penelitian ini menunjukan, bahwa sanksi dari tindakan indisipliner berpengaruh signifikan terhadap kinerja karyawan sebesarnya $82.2 \%$; dan sisanya dipengaruhi oleh variabel-variabel lain yang tidak diteliti.

Disiplin merupakan sarana untuk melatih kepribadian pegawai agar senantiasa menunjukan kinerja yang baik sikap, perilaku dan pola kehidupan yang baik dan berdisiplin tidak terbentuk dalam waktu yang lama, salah satu proses untuk membentuk kepribadian tersebut dilakukan melalui proses latihan. Disiplin berfungsi sebagai pemaksaan atas seseorang untuk mengikuti peraturanperaturan yang berlaku dilingkungan tersebut dengan pemaksaan, pembiasaan dan latihan disiplin seperti itu dapat menyadarkan bahwa disiplin itu penting.

Pada awalnya mungkin disiplin itu berat karena suatu pemaksaan, namun karena adanya pembiasaan dan proses latihan yang terus-menerus maka disiplin dilakukan atas kesadaran dalam diri sendiri dan dirasakan sebagai kebutuhan dan kebiasaan. Diharapkan utuk dikemudian hari, disiplin ini meningkat menjadi kebiasaan berfikir baik, positif bermakna dan memandang jauh ke depan disiplin bukan hanya soal mengikuti dan 
mentaati peraturan, melainkan sudah meningkat menjadi disiplin berfikir yang mengatur dan mempengaruhi seluruh aspek kehidupannya.

Disiplin yang disertai ancaman sanksi atau hukuman sangat penting karena dapat memberikan dorongan kekuatan untuk mentaati dan mematuhinya tanpa ancaman, sanksi atau hukuman, dorongan ketaatan dan kepatuhan dapat menjadi lemah serta motivasi untuk mengikuti aturan yang berlaku menjadi kurang. Dari hasil pendapat para dapat disimpulkan bahwa kinerja pegawai akan baik apabila mendapat dukungan dari pihak manajemen serta memberikan arahan dan memaksimal dengan kondisi kerja para pegawai dan semuanya itu tidak terlepas dari apa yang mereka dapatkan sesuai dengan apa yang mereka kerjakan, serta penerapan kedisiplinan yang merata dan bersikap adil terhadap para pegawai dalam menegakkan kedisiplinan.

Tabel 7. Hasil Uji Autokorelasi Data

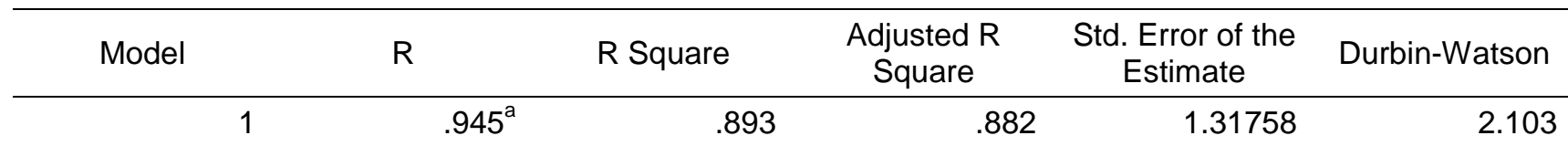

a. Predictors: (Constant), PKPB, PJ, PHK, PP

b. Dependent Variable: Kinerja

Sumber: Data primer diolah, 2018.

\section{KESIMPULAN}

Dalam pelaksanaan tugas sehari-hari kedisiplinan sering menjadi kendala dalam sebuah organisasi, rendahnya kedisiplinan menjadi persoalan yang berulang-ulang terjadi. Pelaksanaan saksi atas pelanggaran disiplin dengan memberikan peringatan, harus segera, konsisten, dan impersonal. Jadi tinggi rendahnya kinerja yang dihasilkan oleh karyawan juga dipengaruhi oleh disiplin kerja, semakin tinggi tingkat kedisiplinan karyawan maka semakin tinggi tingkat kinerja yang dihasilkan dan semakin rendah tingkat kedisiplinan karyawan maka semakin rendah juga tingkat kinerja yang dihasilkan.

Dari hasil penelitian diperoleh beberapa hal sebagai berikut:

1. Penurunan jabatan berpengaruh negatif terhadap kinerja karyawan, yaitu sebesar $-16,2 \%$

2. Pemindahan posisi berpengaruh signifikan terhadap kinerja karyawan, yaitu sebesar 47,9\%.

3. Pemutusan hubungan kerja berpengaruh signifikan terhadap kinerja karyawan, yaitu sebesar 59,3\%.

4. Pengaduan kepada pihak berwajib tidak berpengaruh terhadap kinerja karyawan.
Berdasarkan kesimpulan yang telah dinyatakan, maka dapat dikemukakan beberapa saran guna meningkatkan kinerja karyawan, sebagai berikut:

1. Dalam hal penurunan jabatan hanya memberikan pengaruh yang negatif dan untuk itu pihak perusahaan agar dapat mengkajian ulang kembali dengan keputusan yang telah diambil.

2. Pengaduan kepada pihak berwajib tidak memberikan efek jera terhadap tindakan yang telah dilakukan, hal ini harus dapat diteliti kembali atas apa yang menjadi penyebab sebenarnya, dan memahami kenapa hal itu tidak berpengaruh.

\section{DAFTAR PUSTAKA}

Afandi, P. 2018. Manajemen Sumber Daya Manusia. Pekanbaru: Zanafa Publishing.

Fahmi I, 2017. Manajemen Sumber Daya Manusia: Teori dan Aplikasi, Bandung: Alfabeta.

Ghozali, I. 2016. Aplikasi Analisis Multivariat. Semarang: Undip.

Mulyadi. 2015. Manajemen Sumber Daya Manusia. Bogor: In Media. 
Nurmansyah, S.R. 2014. Manajemen Sumber Daya Manusia Strategik. Pekanbaru: Unilak Press.

Riduwan. 2010. Metode dan Teknik Menyusun Proposal Penelitian. Bandung: Alfabeta.

Sekaran, U. 2007. Research Methods for Business. Jakarta: Salemba Empat.
Sunyoto, D. 2013. Metodologi Penelitian Akuntasi. Bandung: PT. Refika Aditama.

Sutrisno, E. 2015. Manajemen Sumber Daya Manusia. Cetakan ke-7. Jakarta: Kencana. 